\title{
Selective top-down control of epiphytic biomass by amphipods from Posidonia oceanica meadows: implications for ecosystem functioning
}

\author{
Loïc N. Michel ${ }^{1,2, *}$, Patrick Dauby ${ }^{2}$, Alessandra Dupont ${ }^{3}$, Sylvie Gobert ${ }^{1}$ \\ \& Gilles Lepoint ${ }^{1}$
}

\author{
1 Laboratory of Oceanology, MARE Centre, University of Liège, Liège, Belgium \\ 2 Laboratory of Systematics and Animal Diversity, MARE Centre, University of Liège, Liège, Belgium \\ 3 Department of Genetics, Evolution and Environment, University College London, London, United Kingdom \\ * Corresponding author: loicnmichel@gmail.com
}

\begin{abstract}
Mediterranean Posidonia oceanica meadows shelter an important biomass and biodiversity of amphipod crustaceans that graze on epiphytes. However, their actual significance for ecosystem functional processes is hard to estimate, due to the lack of adequate data. Here, a field microcosm-based inclusion experiment was used to test if three of the dominant taxa of the amphipod community (Apherusa chiereghinii, Dexamine spiniventris and Gammarus spp.) could exert top-down control on seagrass leaf epiphytes. Influence of amphipod activity on nutrient availability for the host species was also investigated. All grazer taxa significantly reduced biomasses of erect macroalgae and erect sessile animals present on leaves. None of them consumed encrusting epiflora or epifauna. This selective top-down control could have important implications for the structure of the epiphytic community on leaves of $P$. oceanica, which is one of the most diverse and abundant of all seagrass species. Grazing activity of all taxa caused higher N content of seagrass leaves, likely through amphipod excretion and/or sloppy feeding. Since $P$. oceanica meadows often grow in oligotrophic zones where plant growth can be nutrient-limited, this $\mathrm{N}$ enrichment could enhance seagrass production. Overall, the ecological interaction between P. oceanica and amphipods could be seen as a facultative mutualistic relationship. Our results suggest that amphipod mesograzers are key-elements in some of the functional processes regulating these complex and yet endangered ecosystems, which are essential components of Mediterranean coastal zones.
\end{abstract}

KEY WORDS: Epiphyte grazing, mesograzers, Amphipoda, nutrient cycling, Posidonia oceanica

\section{INTRODUCTION}

Seagrasses are widespread foundation species, present in many coastal zones throughout the world. They form meadows that constitute key coastal ecosystems, and whose paramount ecological importance is widely recognized (DUARTE 2002; VALENTINE \& DUFFy 2006). In several (putatively all) meadow ecosystems, the seagrass, the epiphytes that grow on it and the grazers able to consume either the seagrass or its epiphytes are linked by a complex and intricate interplay of reciprocal interactions and feedback loops, termed seagrass/epiphyte/ grazer system (JERNAKOFF et al. 1996). Natural or anthropogenic fluctuations in this system can influence many ecological processes, and ultimately impact the whole meadow functioning (VALENTINE \& DuFFY 2006).

The Neptune grass, Posidonia oceanica (L.) Delile, is the most widespread seagrass of the Mediterranean Sea. This species is endemic to the Mediterranean and forms large, typically monospecific and fully submerged meadows from shallow depths to 45 meters. The complex tridimensional structure of these meadows offers a suitable habitat to hundreds of animal and plant species, as well as micro-organisms (BUIA et al. 2000). In addition, P. oceanica supports complex, elaborate food webs (VIZZINI 2009). As a result, $P$. oceanica meadows, which 
cover up to $50000 \mathrm{~km}^{2}$ (BETHOUX \& COPINMONTÉGUT 1986), are biodiversity hotspots in the Mediterranean Sea.

P. oceanica is a large (leaf length up to $150 \mathrm{~cm}$ ) and long-lived (leaf life span of 9-12 months) seagrass (GOBERT et al. 2006). These features allow the development of unique epiphytic communities (sensu BOROWITZKA et al. 2006; i.e. all organisms attached to the exterior surface of the plant). They are one of the most diverse and well-structured communities among all seagrasses, and can represent up to $40 \%$ of the foliar biomass (MAZzELLA et al. 1989). Epiphytes cover all parts of the plant (leaf and rhizomes) and include bacteria, fungi, protozoa, microalgae, macroalgae (mostly crustose and erect Rhodophyta and Phaeophyta), as well as encrusting or erect sessile invertebrates, mainly represented by bryozoans, hydrozoans and polychaetes (BUIA et al. 2000). The epiphytic cover is an essential compartment of Neptune grass meadows, and a key feature of $P$. oceanicaassociated food webs. Since they have a higher nutritional quality and a better palatability than seagrass leaves or detritus, epiphytes are readily consumed by various animal taxa (LEPOINT et al. 2000; VIZZINI 2009).

Amphipods (Arthropoda, Malacostraca) are, alongside gastropods and polychaetes, one of the dominant groups of vagile invertebrates found in P. oceanica meadows (GAMBI et al. 1992). They form an abundant and diverse community, whose dominant taxa graze on epiphytes (LEPOINT ET AL. 2000; VIZZINI et al. 2002) with species-specific dietary preferences (MICHEL et al. in press). Since many fishes rely on them as prey (BELL \& HARMELIN-VIVIEN 1983; PINNEGAR \& POLUNIN 2000), amphipods constitute an important trophic link to higher trophic levels. However, the ecological significance of these trophic links at the scale of the meadow ecosystem, as well as their functional implications, remain unclear.

In a number of other temperate seagrass systems, amphipod mesograzers (sensu BRAWLEY 1992; i.e. organisms whose body size is larger than that of a copepod, but smaller than $2.5 \mathrm{~cm}$ ) can exert top-down control on epiphytic assemblages (HOWARD 1982; NECKLES et al. 1993; JERNAKOFF \& NiELSEN 1997; DUfFy \& HARVILICZ 2001). By doing so, they can release the seagrass from competition for nutrients and/ or light, and have positive, indirect effects on seagrass biomass (DUFFY et al. 2001; MYERS \& HECK 2013), production (NECKLES et al. 1993), or density (WHALEN et al. 2013). Moreover, mesograzers are able, through direct or indirect interactions, to act as regulators and to dampen impacts of environmental changes on meadow ecosystems (e.g. AlsterberG et al. 2013). In $P$. oceanica meadows, gastropods have received some attention (GACIA et al. 2009), but no data exist concerning the influence of epiphyte/ amphipod trophic relationships on meadow ecosystem functioning. This limits insights about the actual ecological role of these potentially important mesograzers.

In this context, the objectives of this study were 1) to quantify the impact of amphipod feeding on the epiphytic cover of the leaves of $P$. oceanica and 2) to investigate potential indirect effects of amphipods on their seagrass host. To achieve these goals, we tested the impact of grazer inclusion on biomass of epiphytic functional groups and $\mathrm{C} / \mathrm{N}$ ratios of $P$. oceanica leaves using in situ microcosms. To account for potential interspecific differences, experiments were focused on three of the dominant species of the community, i.e. Apherusa chiereghinii GiordaniSoika, 1949, Dexamine spiniventris (Costa, 1853) and Gammarus aequicauda (Martynov, 1931). These species display contrasting feeding habits and, taken together, they represent about $60 \%$ of the total amphipod abundance in Calvi Bay (MiCHEL 2011; MiCHEL et al. in press).

Neptune grass meadows, like most seagrass ecosystems worldwide, are currently threatened by human activities (DUARTE 2002). Through this work, our ultimate goal is to put the trophic relationship between leaf epiphytes and amphipod mesograzers in the wider context of meadow functioning, and therefore to improve 
the knowledge of ecological interactions among this remarkably important, yet endangered, ecosystem.

\section{MATERIALS AND METHODS}

Experiments were carried out in Calvi Bay (western Mediterranean Sea, north-western Corsica, France). Posidonia oceanica meadows cover about $50 \%$ of this bay, and reach depths of nearly $40 \mathrm{~m}$. Meadows of Calvi Bay are mostly characterized by a continuous extension, and show important foliar biomass and production (BAY 1984; GOBERT et al. 2003). Work was undertaken by scuba diving in the surroundings of the STARESO research station (University of Liège). A circular (radius: $10 \mathrm{~m}$, center coordinates: $42^{\circ} 34^{\prime} 46^{\prime \prime} \mathrm{N}, 8^{\circ} 43^{\prime} 32^{\prime \prime} \mathrm{E}$ ) experimental site was set up in a continuous meadow zone. Depth of the experimental site ranged from 9.5 to $11 \mathrm{~m}$. Meadow density at site depth was $314 \pm 121$ shoots. $\mathrm{m}^{-2}$ (mean \pm SD of 45 measurements).

In situ microcosms were set up in this site, directly in the $P$. oceanica meadow. They consisted of $400-\mu \mathrm{m}$ nylon mesh cylinders (20 cm diameter X $180 \mathrm{~cm}$ length). Terminal portions (last $15 \mathrm{~cm}$ ) of each end were made of elastic fabric, to facilitate microcosm opening, closing and sealing. To place microcosms, a patch of circa $10 \mathrm{P}$. oceanica shoots was randomly selected. Vagile fauna was eliminated by gently shaking the seagrass leaves, in order to cause grazer displacement without destroying the epiphytic cover. Each microcosm was then placed around the leaves. The bottom elastic part was tied around the rhizomes of the shoots, so that amphipods only had access to the foliar stratum. Microcosms were sealed as tight as possible using large plastic cable ties. In addition, each microcosm was anchored to the ground using 2 metal stakes. A float was attached to the top part to ensure adequate position of the microcosm in the water column. Four treatments were considered: one control without grazers, and three others, each containing a single grazer taxon. Each treatment was replicated twice, giving a total of 8 microcosms. In addition, a procedural control consisting of a patch of 10 shoots without microcosm was realized, to ensure that the microcosm itself had no effect on the epiphyte community or the seagrass, notably through shading.

Amphipods were sampled using light traps which were modified after those described by Michel et al. (2010). Each live animal was identified through direct observation and photographs. The accuracy of these identifications was checked at the end of the experiment. All identifications were correct in the cases of Apherusa chiereghinii and Dexamine. spiniventris. However, a minor proportion (about 5\%) of animals considered as being Gammarus aequicauda actually belonged to the morphologically close Gammarus crinicornis Stock, 1966 or Gammarus subtypicus Stock, 1966. Consequently, they will be referred to as "Gammarus spp." over the course of this article.

Body size differed across grazer taxa. Specimens of A. chiereghinii (total body length $5.48 \pm 1.17 \mathrm{~mm}$; mean $\pm \mathrm{SD}$ ) were much smaller than those of $D$. spiniventris (total body length $9.89 \pm 1.59 \mathrm{~mm}$; mean $\pm \mathrm{SD}$ ) or Gammarus spp. (total body length $12.41 \pm 2.59 \mathrm{~mm}$; mean $\pm \mathrm{SD}$ ). To account for these differences, different grazer population sizes were used (50 individuals for $A$. chiereghinii, 20 individuals for $D$. spiniventris and Gammarus spp.). These populations respectively correspond to amphipod densities of 707 and 283 ind. $\mathrm{m}^{-2}$, and are within the range commonly encountered in Calvi bay (87-1028 ind.m ${ }^{-2}$; STURARO et al. 2015). In all cases, only individuals that could clearly be identified as adults were selected.

Amphipods were added to the corresponding microcosms on 9 June 2009 for one replicate of each treatment, and on 10 June 2009 for the other replicate. During the course of the experiment, maintenance dives were performed twice a week to ensure the metal stakes remained in place, and to gently scrub off the epiphytes that developed 
on the microcosm mesh with a soft brush. The experiment ended after 21 days. At this stage, all P. oceanica shoots were cut at the rhizome level, and the microcosms were brought back to the laboratory unopened for processing.

Each seagrass shoot ( $\mathrm{n}=7$ to 11 , according to the microcosm) was processed separately. $P$. oceanica leaves were checked for grazing marks, and their epiphytes were scraped under a binocular microscope, using a scalpel blade. They were separated into four functional groups according to LEPOINT et al. (2007): erect algae (also referred to as "erect epiflora"), encrusting algae (= "encrusting epiflora"), erect animals (= "erect epifauna") and encrusting animals (= "encrusting epifauna"). Seagrass tissues, epiphytes and grazers were ovendried at $60^{\circ} \mathrm{C}$ for $72 \mathrm{~h}$, and their biomass was subsequently determined using an analytical balance (AX105 DeltaRange, Mettler-Toledo, Greifensee, Switzerland). Reproducibility range of successive weighings was $\pm 0.04 \mathrm{mg}$.

The basal portions (first $5 \mathrm{~cm}$ ) of each seagrass leaf blade were cut. All leaf fragments originating from the same shoot were grouped together and ground to a homogeneous powder. Carbon and nitrogen contents of seagrass leaves were determined using a NA1500 elemental analyzer (Carlo Erba, Milano, Italy). Glycine (Merck, Darmstadt, Germany) was used as a standard for elemental contents measures. Analytical precision was $2 \%$ of the relative content of samples (i.e. $0.6 \%$ for a sample containing 30\% of a given element). $\mathrm{C} / \mathrm{N}$ ratios were calculated using relative organic $\mathrm{C}$ and $\mathrm{N}$ contents, both expressed in percentage of total dry mass.

Inter-treatment differences of measured parameters were tested using analysis of variance followed by multiple comparison procedures. Since Shapiro-Wilk normality tests revealed that several datasets did not follow a Gaussian distribution, data were log-transformed. Individual shoot measurements were analyzed through nested 1-way ANOVA using "treatment" as a fixed factor and "microcosm" as a random factor nested within treatment. When differences among treatments were present, they were explored using Tukey's HSD post-hoc test. All statistical analyses were conducted using JMP 9.0.0 (SAS Software, Cary, U.S.A.).

\section{RESULTS}

Survival rate was low for Apherusa chiereghinii (18\%; final grazer density 127 ind. $\mathrm{m}^{-2}$ ), but much higher for Dexamine spiniventris $(80 \%$; final grazer density 226 ind. $\mathrm{m}^{-2}$ ). It was $115 \%$ in Gammarus spp. (final grazer density 325 ind. $\mathrm{m}^{-2}$ ), suggesting that animals reproduced over the course of the experiment. All microcosms, including control treatments, were contaminated with non-amphipod invertebrates (gastropods or copepod crustaceans), indicating that the defaunation step may not have been sufficient. However, biomass of these undesired animals was always low (less than $5 \%$ of amphipod grazer biomass) and was comparable across treatments. It was therefore assumed that their impact was negligible in regard to changes

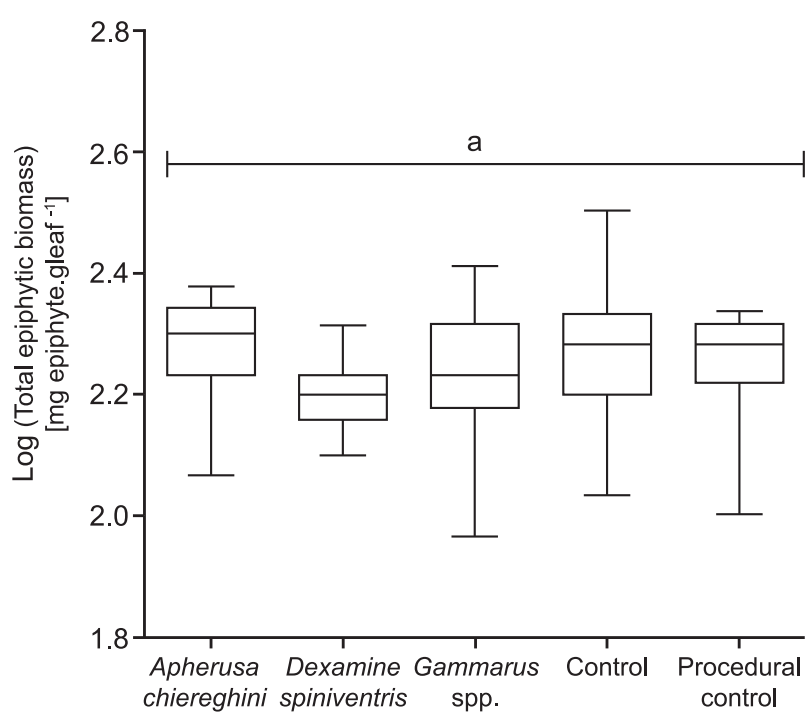

Fig. 1. - Biomass of total epiphytes in each treatment at the end of the grazing experiment, expressed in $\mathrm{mg}$ of epiphytes per gram of Posidonia oceanica leaf. Central black bars represent medians, box limits are upper and lower quartiles, and error bars represent the full range of the data (minimum-maximum). Different letters indicate statistically different groups (1-way ANOVA \& Tukey's HSD post-hoc test, $\mathrm{p}<0.05$ ). 
caused by introduced amphipods. No unplanned amphipod grazers were observed.

At the end of the experiment, the total biomass of epiphytes present on Posidonia oceanica leaves (Fig. 1) was similar across treatments (1-way ANOVA, $\mathrm{F}_{4,73}=1.70, \mathrm{p}=$ 0.3167 ), suggesting presence of grazers had no significant effect on the epiphytic community as a whole. However, functional group-specific trends were present (Fig. 2). Grazer presence had no effect on encrusting algae biomass (Fig. 2a; 1-way ANOVA, $\left.\mathrm{F}_{4,73}=1.60, \mathrm{p}=0.3489\right)$, nor on encrusting animals biomass (Fig. 2b; 1 -way ANOVA, $\left.\mathrm{F}_{4,73}=0.57, \mathrm{p}=0.6993\right)$. On the other hand, biomass of erect algae (Fig. 2c) differed across treatments (1-way ANOVA, $\mathrm{F}_{4,73}$ $=41.38, p=0.0032)$. It was significantly lower in all grazed treatments than in the "control" and "procedural control" ones (Tukey's HSD post-hoc test, $\mathrm{p}<0.05$ in each case; Fig. 2c). The situation was similar for erect epifauna (Fig. 2d), whose biomass tended to be lower when amphipods were present (1-way ANOVA, $\left.F_{4,73}=64,36, p=0.0008\right)$. As for erect epiflora, this trend was significant for all three grazed treatments (Tukey's HSD post-hoc test, $p<0.05$ in each case; Fig. 2d).

No seagrass grazing seemed to occur in any of the amphipod-containing microcosms, as no grazing marks or other damage to seagrass
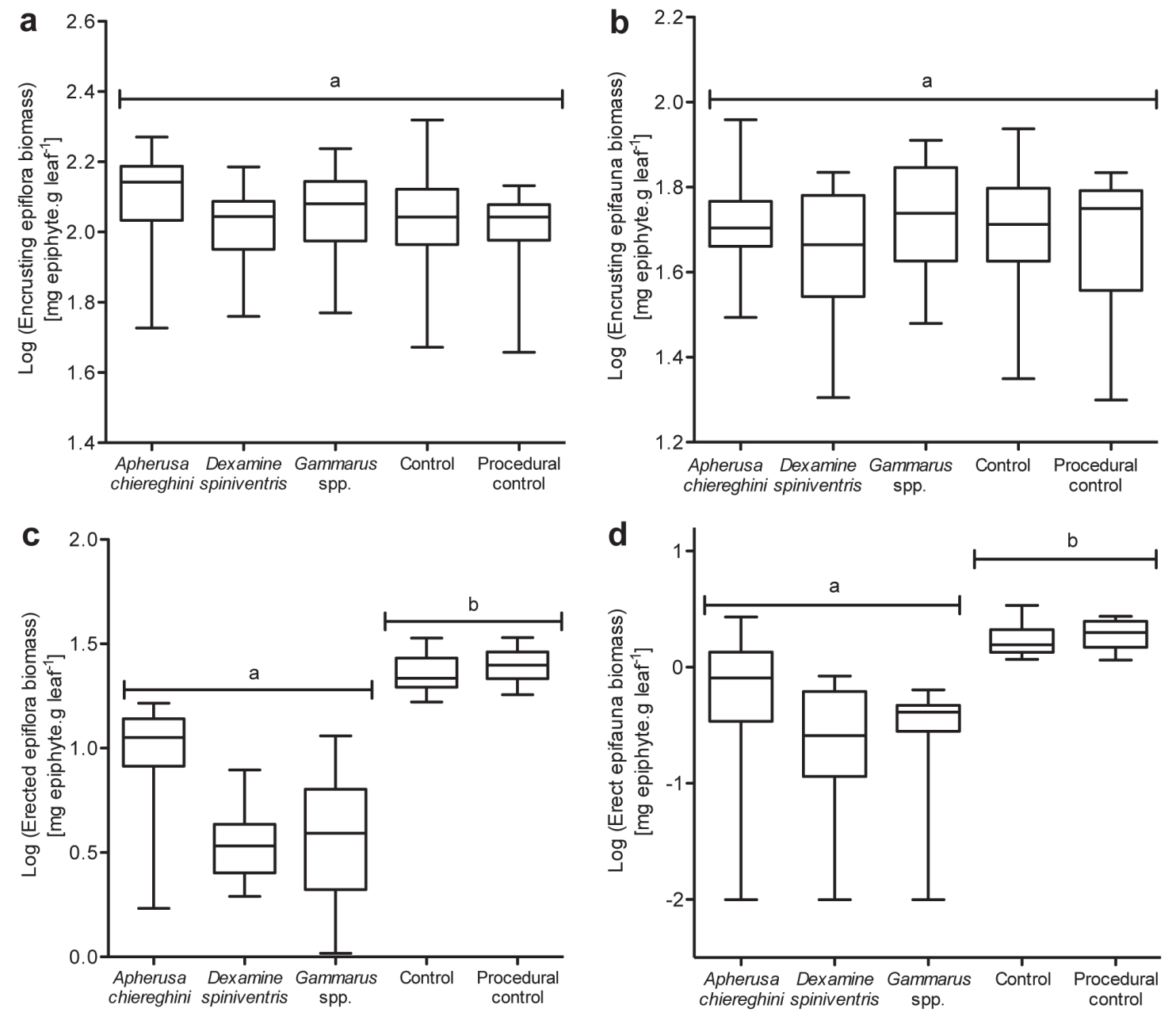

Fig. 2. - Biomass of (a) encrusting algae, (b) encrusting animals, (c) erect algae and (d) erect animals in each treatment at the end of the grazing experiment, expressed in $\mathrm{mg}$ of epiphytes per gram of Posidonia oceanica leaf. Central black bars represent medians, box limits are upper and lower quartiles, and error bars represent the full range of the data (minimum-maximum). Different letters indicate statistically different groups (1-way ANOVA \& Tukey's HSD post-hoc test, $\mathrm{p}<0.05)$. 
leaves were noted. Grazer presence had an effect on the $\mathrm{C} / \mathrm{N}$ ratio of $P$. oceanica leaves (1-way ANOVA, $\mathrm{F}_{4,73}=1041.46, \mathrm{p}<0.0001$; Fig. 3). It was significantly lower in treatments containing grazers than in both control conditions (control and procedural control; Tukey's HSD post-hoc test, $\mathrm{p}<0.05$ in each case). These lower $\mathrm{C} / \mathrm{N}$ ratios were linked with higher $\mathrm{N}$ content of seagrass leaves, as carbon content was similar in all treatments (data not shown).

No significant effect of the "microcosm [treatment]" factor was detected for any of the performed comparisons (Tukey's HSD post-hoc test, $p>0.05$ in each case), indicating that none of the analyzed parameters varied across the two microcosms of a single treatment.

\section{DISCUSSION}

Amphipods from Posidonia oceanica meadows had inconspicuous effects on their host's epiphytic cover. While no effects on total biomass of the epiphytic community, or on the one of crustose morphotypes were seen, the standing stocks of

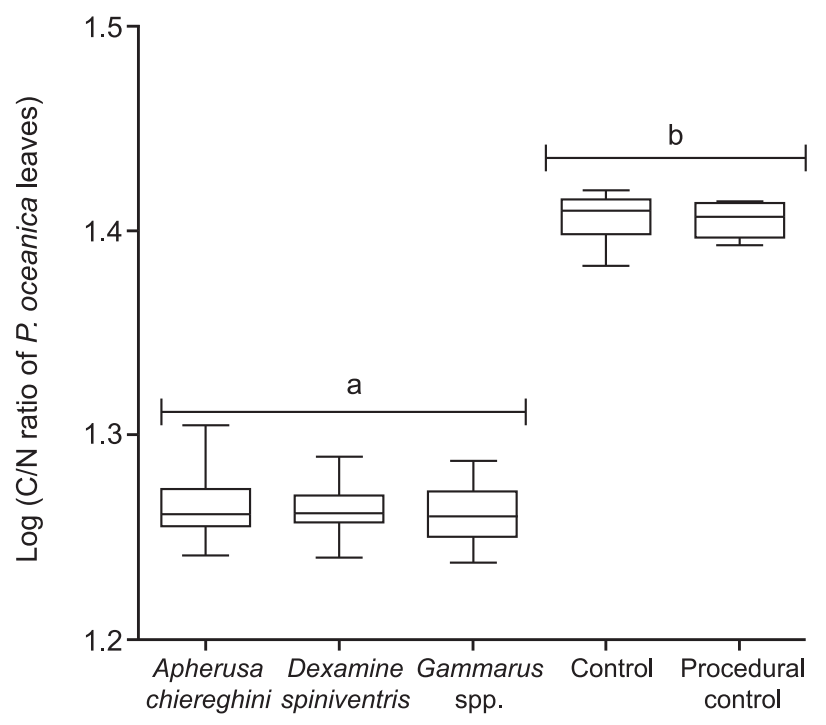

Fig. 3. - C to $\mathrm{N}$ ratio of Posidonia oceanica leaves in each treatment at the end of the grazing experiment. Central black bars represent medians, box limits are upper and lower quartiles, and error bars represent the full range of the data (minimum-maximum). Different letters indicate statistically different groups (1-way ANOVA \& Tukey's HSD post-hoc test, p < 0.05). erect epiphytes were lower in the presence of any of the three grazer taxa. This was the case for algae but also for sessile animals. Depletion of epiphytic micro- or macroalgae by amphipods occurs in a number of temperate and subtropical seagrass systems. Experimental discrepancies, alongside differences in biology and life history of amphipods, result in the scattering of amphipod grazing impacts over a broad spectrum (HUGHES et al. 2004). Strong, marked effects are common. In some cases, exclusion of amphipods can cause an increase of over $400 \%$ of epiphytic biomass (e.g. CAINE 1980; WHALEN et al. 2013). In this study, impacts were less drastic, as amphipods consumed 50 to $90 \%$ of erect algal biomass. This effect is nonetheless more marked than those recorded for other species in different meadows, where amphipods can have moderate and/or low effects on epiphytic abundance (see JASCHINSKI \& SOMMER 2008; COOK et al. 2011). Consumption of sessile animals by amphipods, although apparently less generalized, also occurs in other systems. Amphipod grazers from Zostera marina meadows feed on erect bryozoans and tunicates, but do not seem to consume the crustose species (DUFFY \& HARVILICZ 2001; DOUGLASS et al. 2007). Several of these amphipod taxa can also prey on juvenile bay scallops (Argopecten irradians) during their early life stages, when they live on the $Z$. marina blades (LEFCHECK et al. 2014).

None of the amphipod grazers seemed to consume encrusting epiphytes. This is consistent with widely observed trends of resistance of crustose algae to herbivory (POORE et al. 2012). Here, it could be linked with the feeding mechanism of the studied amphipods. All three taxa, like most herbivorous amphipods, use the typical feeding mode of gammarid amphipods. It involves cutting fragments through an initial bite from the mandible's incisor process before triturating and crushing them with the mandibular molar process. Food pieces are then gathered and brought to the mouth for ingestion (BELLAN-SANTINI 1999). Crustose morphotypes are not easily accessible to this type of feeding, and amphipods might therefore 
simply be unable to consume them. Preferential consumption of erect epiphytes has important implications for the role of amphipod grazers in $P$. oceanica meadows. Their selective grazing pressure may be one of the processes involved in the structuring of the epiphytic cover of seagrass leaves. Discriminatory removal of certain taxa through grazing can indeed relieve the non-consumed species from competition for space, nutrients and/or light, and therefore allow their development and in turn modify the whole epiphytic community structure (JERNAKOFF et al. 1996; JASCHINSKI et al. 2010). On P. oceanica leaves, epiphytic biomass is at its lowest in winter. Organisms start to grow during spring. The fastgrowing erect brown algae typically dominate the community in spring and early summer (May/ June). Crustose epiphytes, such as red coralline algae, are present all year round, but become more and more abundant as the epiphytic cover develops. They are the dominant organisms in late summer, when epiphytic coverage and specific diversity are maximal (MAZZELLA et al. 1989; CEBRIAN et al. 1999; LEPOINT et al. 2000). Amphipods could play a part in this process. By grazing on erect algae, they could limit their biomass, and indirectly favor growth of crustose algae. In doing so, they would participate in the balance between the two epiphytic morphotypes, and allow the epiphytic community to fully develop, and reach its maximal diversity.

Amphipods are not the only mesograzers to impact epiphytic communities in Neptune grass meadows. Gastropods can indeed consume 54 to $70 \%$ of the total epiphytic biomass present on P. oceanica leaves (GACIA et al. 2009). Moreover, in $P$. oceanica meadows, the studied amphipods only consume macroepiphytes (MichEL et al. in press) and only feed on erect morphotypes, while gastropods can use their radula to scrape the surface of the leaves and consume microepiphytes (mostly diatoms and bacteria; PEDUZZI 1987; MAZZELla \& RUSSO 1989; GACIA et al. 2009) and, to a lesser extent, crustose macroepiphytes (MAZZELLA \& RUSSO 1989). The complementarity of feeding modes could lead to synergetic effects of these two grazer taxa on the epiphytic communities, as biodiversity of grazer assemblages can, through horizontal interactions, modulate their influence on other compartments of the ecosystem. (DUFFY et al. 2001; DUFFY et al. 2003).

$\mathrm{C} / \mathrm{N}$ ratios of basal portions of $P$. oceanica leaves were significantly lower in all grazed treatments. This was caused by a generalized trend towards $\mathrm{N}$ enrichment of growing host tissues when grazers were present. This enrichment could simply be an indirect effect of epiphyte consumption. Since epiphytic biomass decreases through grazing, nitrogen availability would be higher for the surviving organisms, leading to an apparent concentration effect. However, since leaf biomass exceeds by far erect macroalgae biomass, it is more likely that other, non-exclusive phenomena occur concomitantly. Grazing activity itself may directly enhance $\mathrm{N}$ cycling by processes such as excretion (fecal pellets and $\mathrm{NH}_{4}^{+}$) and/or sloppy feeding. Excretion of either sessile (e.g. bryozoans; HURD et al. 1994) or vagile (BRACKEN et al. 2007) invertebrates can cause $\mathrm{N}$ enrichment in tissues of host seaweeds. In Zostera marina meadows, slow-moving gastropods can enhance $\mathrm{N}$ content of primary producers, while amphipod and isopod mesograzers fail to do so (JASCHINSKI \& SOMMER 2010). This suggests that enrichment could only occur in the case of a tight association with seagrass leaves, and that dispersal and dilution of waste products would limit the fertilization effect in the case of highly motile and free-swimming crustaceans (JASCHINSKI \& SOMMER 2010). Our results disagree with this hypothesis. The widely different general $\mathrm{N}$ availability in the two systems probably explains most of this difference. The Mediterranean Sea in general, and Calvi Bay in particular, are oligotrophic areas (LEPOINT et al. 2004), where plant growth can be limited by nutrient scarcity. Increase of nutrient supply through grazing could be more crucial there than in Z. marina meadows of the Baltic, and therefore cause stronger and more marked effects. 
Nutrient additions have contrasting impacts on seagrass production (HuGHES et al. 2004). Since epiphytes are often able to use these nutrients more efficiently (higher uptake and growth rates) than the seagrass itself (LEPOINT et al. 2007), they tend to outgrow the seagrass, and can lead to seagrass death in some situations (BOROWITZKA et al. 2006). However, under top-down control of epiphytic growth by mesograzers, this effect is suppressed, and enhanced nutrient availability can have positive effect on seagrass production (HAYS 2005). Growth of $P$. oceanica can be enhanced by in situ nutrient fertilization (AlCoverro et al. 1997). In Calvi Bay meadows, low nutrient availability and constant grazing of fast-growing erect epiphytes by amphipods suggest that $\mathrm{N}$ enrichment could have a positive effect on seagrass growth.

Contrary to other grazer groups, crustaceans globally benefit seagrasses (POORE et al. 2012). However, the interaction between crustaceans and seagrasses can turn antagonistic. Some taxa (idoteid isopods, ampithoid amphipods) graze directly on seagrass tissues when alternative food supplies are low (VALENTINE \& DUfFY 2006). During our experiment, no grazing marks were observed. Moreover, under natural conditions, none of the dominant amphipods of $P$. oceanica meadows feed on their seagrass host (MiCHEL et al. in press). The interaction has therefore no reason to become negative. Instead, amphipod mesograzers have two indirect, putatively positive effects on their seagrass host's production. First, through their feeding activity, they may release Neptune grass from competition for nutrients and/or light with faster-growing erect epiphytes. Second, through excretion and/ or sloppy feeding, they may enhance nutrient cycling, and in turn boost seagrass production. The ecological interaction between $P$. oceanica and amphipod grazers could therefore be seen as a facultative mutualistic relationship, where amphipods would keep biomasses of fastgrowing erect algal competitors at acceptable levels and supply nutrient for host growth, while the seagrass would provide trophic resources for amphipods, as well as a substratum and a shelter from predation (VALENTINE \& DUFFY 2006).
Functional interactions among the seagrass/ epiphyte/grazer system form a complex and entangled network, where multiple factors can directly or indirectly influence plant and animal components (JERNAKOFF et al. 1996). Unraveling the elaborate interactions between Neptune grass, epiphytes growing on its leaves and mesograzers inhabiting its meadows is a complicated task, and requires further work on many aspects. This study nevertheless presented results that constitute, to the best of our knowledge, the first direct, experimental evidence of the importance of amphipod grazers in trophofunctional relationships among Posidonia oceanica meadows. For this reason, it provides another step towards a better comprehension of this complex, pivotal, yet critically endangered, ecosystem.

\section{ACKNOWLEDGEMENTS}

Loïc Michel was a Belgian Funds for Scientific Research (F.R.S-FNRS) research fellow (grant number FC74034). Gilles Lepoint is a F.R.S.FNRS research associate. The authors would like to thank Renzo Biondo (Laboratory of Oceanology, ULg) for his technical assistance in the conception and building of sampling and experimental gear, the staff of the STARESO Research station for their help during the fieldwork, and Joseph G. Schnitzler (Laboratory of Oceanology, ULg) for his assistance with statistical analyses. Constructive comments from Dorothée Pête (Laboratory of Oceanology, ULg) and from two anonymous reviewers helped to improve earlier versions of this article. This paper is MARE publication nr. 291.

\section{REFERENCES}

Alcoverro T, Romero J, DuARTE CM \& LOPEZ NI (1997). Spatial and temporal variations in nutrient limitation of seagrass Posidonia oceanica growth in the NW Mediterranean. Marine Ecology Progress Series, 146: 155-161.

AlsterbergC, EKLOF JS, GAMFELDTL, HAVENHAND JN \& SUNDBACK K (2013). Consumers mediate 
the effects of experimental ocean acidification and warming on primary producers. Proceedings of the National Academy of Sciences of the United States of America, 110(21): 8603-8608.

BAY D (1984). A field study of the growth dynamics and productivity of Posidonia oceanica (L.) Delile in Calvi Bay, Corsica. Aquatic Botany, 20(1-2): 43-64.

BELL JD \& HARMELIN-VIVIEN ML (1983). Fish fauna of French Mediterranean Posidonia oceanica seagrass meadows. 2. Feeding habits. Tethys, 11: 1-14.

Bellan-SAnTini D (1999) Ordre des Amphipodes (Amphipoda Latreille, 1816). In: Forest J (ed), Traité de Zoologie - Anatomie, Systématique, Biologie (Pierre-P. Grassé). Tome VII, Fascicule III A : Crustacés Péracarides. Institut Océanographique de Monaco, Monaco: 93-176.

Bethoux J \& Copin-Montégut G (1986). Biological fixation of atmospheric nitrogen in the Mediterranean Sea. Limnology and Oceanography, 31(6): 1353-1358.

BOROWITZKa MA, LAVERY P \& VAN KEULEN M (2006) Epiphytes of seagrasses. In: LARKUM AWD, ORTH RJ \& DUARTE CM (eds), Seagrasses: Biology, Ecology and Conservation. Springer: 441-461.

BRACKEN MES, GONZALEZ-DORANTES CA \& STACHOWICZ JJ (2007). Whole-community mutualism: associated invertebrates facilitate a dominant habitat-forming seaweed. Ecology, 88(9): 2211-2219.

BRAWLEY HS (1992) Mesoherbivores. In: JOHN DM, HAWKINS SJ \& PRICE JH (eds), Plant-Animal Interactions in the Marine Benthos. Clarendon Press, Oxford: 235-263.

BuIA MC, GAMBI MC \& ZuPO V (2000). Structure and functioning of Mediterranean seagrass ecosystems: an overview. Biologia Marina Mediterranea, 7: 167-190.

CAINE EA (1980). Ecology of two littoral species of caprellid amphipods (Crustacea) from Washington, USA. Marine Biology, 56(4): 327335 .

Cebrian J, EnRiquez S, Fortes M, Agawin N, VERMAAT JE \& DUARTE CM (1999). Epiphyte accrual on Posidonia oceanica (L.) Delile leaves: implications for light absorption. Botanica Marina, 42: 123-128.
Cook K, VAnderklift MA \& Poore AGB (2011). Strong effects of herbivorous amphipods on epiphyte biomass in a temperate seagrass meadow. Marine Ecology Progress Series, 442: 263-269.

Douglass JG, Duffy JE, SPIVAK C \& Richardson JP (2007). Nutrient versus consumer control of community structure in a Chesapeake Bay eelgrass habitat. Marine Ecology Progress Series, 348: 71-83.

DUARTE CM (2002). The future of seagrass meadows. Environmental Conservation, 29(2): 192-206.

DUFFY JE \& HARVILICZ AM (2001). Species-specific impacts of grazing amphipods in an eelgrass-bed community. Marine Ecology Progress Series, 223: 201-211.

DufFy JE, RichaRdson JP \& CANUEL EA (2003). Grazer diversity effects on ecosystem functioning in seagrass beds. Ecology Letters, 6: 637-645.

Duffy JE, MacDonald KS, RHode JM \& PARKER JD (2001). Grazer diversity, functional redundancy, and productivity in seagrass beds: an experimental test. Ecology, 82(9): 2417-2434.

Gacia E, Costalago D, Prado P, Piorno D \& Tomas F (2009). Mesograzers in Posidonia oceanica meadows: an update of data on gastropodepiphyte-seagrass interactions. Botanica Marina, 52(5).

GAMBI MC, LORENTI M, RUSSO GF, SCIPIONE MB \& ZUPO V (1992). Depth and seasonal distribution of some groups of the vagile fauna of the Posidonia oceanica leaf stratum: Structural and trophic analyses. Marine Ecology, 13(1): 17-39.

Gobert S, Kyramarios M, Lepoint G, PergentMARTINI C \& BOUQUEGNEAU JM (2003). Variations at different spatial scales of Posidonia oceanica (L.) Delile beds; effects on the physico-chemical parameters of the sediment. Oceanologica Acta, 26(2): 199-207.

Gobert S, CAmbridge ML, Velimirov B, Pergent G, Lepoint G, Bouguegneau JM, Dauby P, Pergent-Martini C \& Walker DI (2006) Biology of Posidonia. In: LARKUM AWD, ORTH RJ \& DuARTe CM (eds), Seagrasses : Biology, Ecology and Conservation: 387-408.

HAYS CG (2005). Effect of nutrient availability, grazer assemblage and seagrass source population on the interaction between Thalassia testudinum (turtle grass) and its algal epiphytes. Journal of Experimental Marine Biology and Ecology, 314(1): 53-68. 
HOWARD RK (1982). Impact of feeding activities of epibenthic amphipods on surface-fouling of eelgrass blades. Aquatic Botany, 14: 91-97.

Hughes AR, BANDO KJ, RODRIGUEZ LF \& WiLLIAMS SL (2004). Relative effects of grazers and nutrients on seagrasses: a meta-analysis approach. Marine Ecology Progress Series, 282: 87-99.

Hurd CL, Durante KM, Chia FS \& Harrison PJ (1994). Effect of bryozoan colonization on inorganic nitrogen acquisition by the kelps Agarum fimbriatum and Macrocystis integrifolia. Marine Biology, 121(1): 167-173.

JASCHINSKI S \& SOMMER U (2008). Functional diversity of mesograzers in an eelgrass-epiphyte system. Marine Biology, 154(3): 475-482.

JASCHINSKI S \& SOMMER U (2010). Positive effects of mesograzers on epiphytes in an eelgrass system. Marine Ecology Progress Series, 401: 77-85.

JASCHINSKI S, FLÖDER S \& SOMMER U (2010). Consumer identity, abundance and nutrient concentration affect epiphyte diversity in an experimental eelgrass system. Oikos, 119(11): $1745-1754$.

JERNAKOFF P \& NIELSEN J (1997). The relative importance of amphipod and gastropod grazers in Posidonia sinuosa meadows. Aquatic Botany, 56(3-4): 183-202.

JeRNAKofF P, BREARLEY A \& NiELSEN J (1996). Factors affecting grazer-epiphytes interactions in temperate seagrass meadows. Oceanography and Marine Biology: an Annual Review, 34: 109-162.

LEFCHECK JS, VAN MONTFRANS J, ORTH RJ, SCHMITT EL, DuFFY JE \& LUCKENBACH MW (2014). Epifaunal invertebrates as predators of juvenile bay scallops (Argopecten irradians). Journal of Experimental Marine Biology and Ecology, 454: 18-25.

Lepoint G, Gobert S, DAuby P \& Bouguegneau JM (2004). Contributions of benthic and planktonic primary producers to nitrate and ammonium uptake fluxes in an nutrient-poor shallow coastal area (Corsica, NW Mediterranean). Journal of Experimental Marine Biology and Ecology, 302: 107-122.

Lepoint G, NySSEN F, Gobert S, DAuby P \& BOUQUEGNEAU J-M (2000). Relative impact of a seagrass bed and its adjacent epilithic algal community in consumer diets. Marine Biology, 136: 513-518.
Lepoint G, JACQUemart J, BOUQUegneau JM, DEMOULIN V \& GOBERT S (2007). Field measurements of inorganic nitrogen uptake by epiflora components of the seagrass Posidonia oceanica (Monocotyledons, Posidoniaceae). Journal of Phycology, 4(2): 208-218.

MAZZELLA L \& RUSSO GF (1989). Grazing effect of two Gibbula species (Mollusca, Archaeogastropoda) on the epiphytic community of Posidonia oceanica leaves. Aquatic Botany, 35: 353-373.

MAZZella L, SCIPIONE MB \& BUiA MC (1989). Spatio-temporal distribution of algal and animal communities in a Posidonia oceanica meadow. Marine Ecology, 10(2): 107-129.

MiCHEL L (2011). Multidisciplinary study of trophic diversity and functional role of amphipod crustaceans associated to Posidonia oceanica meadows. PhD in Sciences thesis, University of Liège, Belgium.

Michel L, Lepoint G, Dauby P \& Sturaro N (2010). Sampling methods for amphipods of Posidonia oceanica meadows: a comparative study. Crustaceana, 83(1): 39-47.

Michel LN, Dauby P, Gobert S, Graeve M, Nyssen F, THELEN N \& Lepoint G (in press). Dominant amphipods of Posidonia oceanica seagrass meadows display considerable trophic diversity. Marine Ecology.

Myers JA \& HeCK KLJ (2013). Amphipod control of epiphyte load and the concomitant effects on shoalgrass Halodule wrightii biomass. Marine Ecology Progress Series, 483: 133-142.

NeCKLES HA, Wetzel RL \& ORTH RJ (1993). Relative effects of nutrient enrichment and grazing on epiphyte-macrophyte (Zostera marina L.) dynamics. Oecologia, 93: 285-295.

PEDUZZI P (1987). Dietary preferences and carbon absorption by two marine gastropods, Gibbula umbilicaris (Linné) and Jujubinus striatus (Linné). Marine Ecology, 8(4): 359-370.

PINNEGAR JK \& Polunin NVC (2000). Contributions of stable-isotope data to elucidating food webs of Mediterranean rocky littoral fishes. Oecologia, 122(3): 399-409.

PoOre AG, CAMPBell AH, COLEMAN RA, Edgar GJ, JORMALAINEN V, REYNOLDS PL, SOTKA EE, STACHOWICZ JJ, TAYLOR RB, VANDERKLIFT MA \& DUFFY JE (2012). Global patterns in the impact of marine herbivores on benthic primary producers. Ecological Letters, 15(8): 912-922. 
Sturaro N, Lepoint G, Vermeulen S \& Gobert S (2015). Multiscale variability of amphipod assemblages in Posidonia oceanica meadows. Journal of Sea Research, 95: 258-271.

VALENTINE JF \& DUFFY JE (2006) The central role of grazing in seagrass ecology. In: LARKUM AWD, ORTH RJ \& DUARTE CM (eds), Seagrasses: Biology, Ecology and Conservation. Springer: 463-501.

VizZINI S (2009). Analysis of the trophic role of Mediterranean seagrasses in marine coastal ecosystems: a review. Botanica Marina, 52(5): 383-393.

VizZINI S, SARÀ G, Michener RH \& MAZZOla A (2002). The role and contribution of the seagrass Posidonia oceanica (L.) Delile organic matter for secondary consumers as revealed by carbon and nitrogen stable isotope analysis. Acta Oecologica, 23: 277-285.

Whalen MA, DufFy JE \& GRACE JB (2013). Temporal shifts in top-down vs. bottom-up control of epiphytic algae in a seagrass ecosystem. Ecology, 94(2): 510-520.

Received: October 10th, 2014

Accepted: March 19th, 2015

Branch editor: Isa Schön 